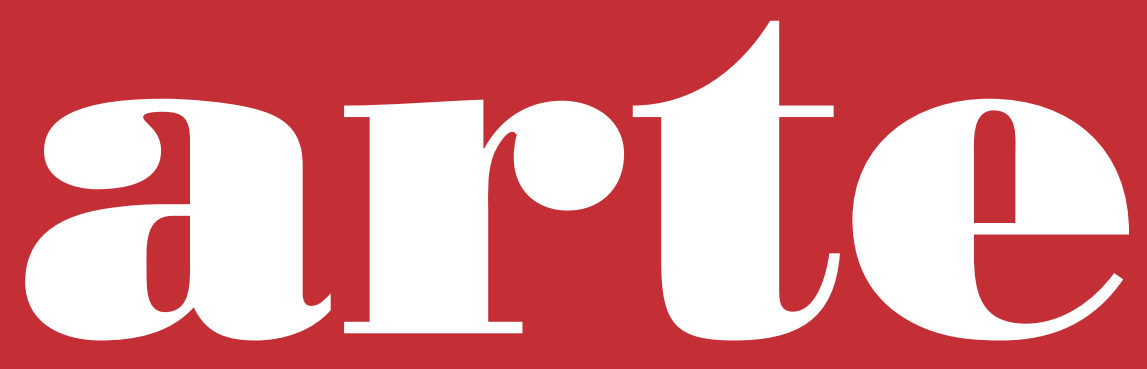




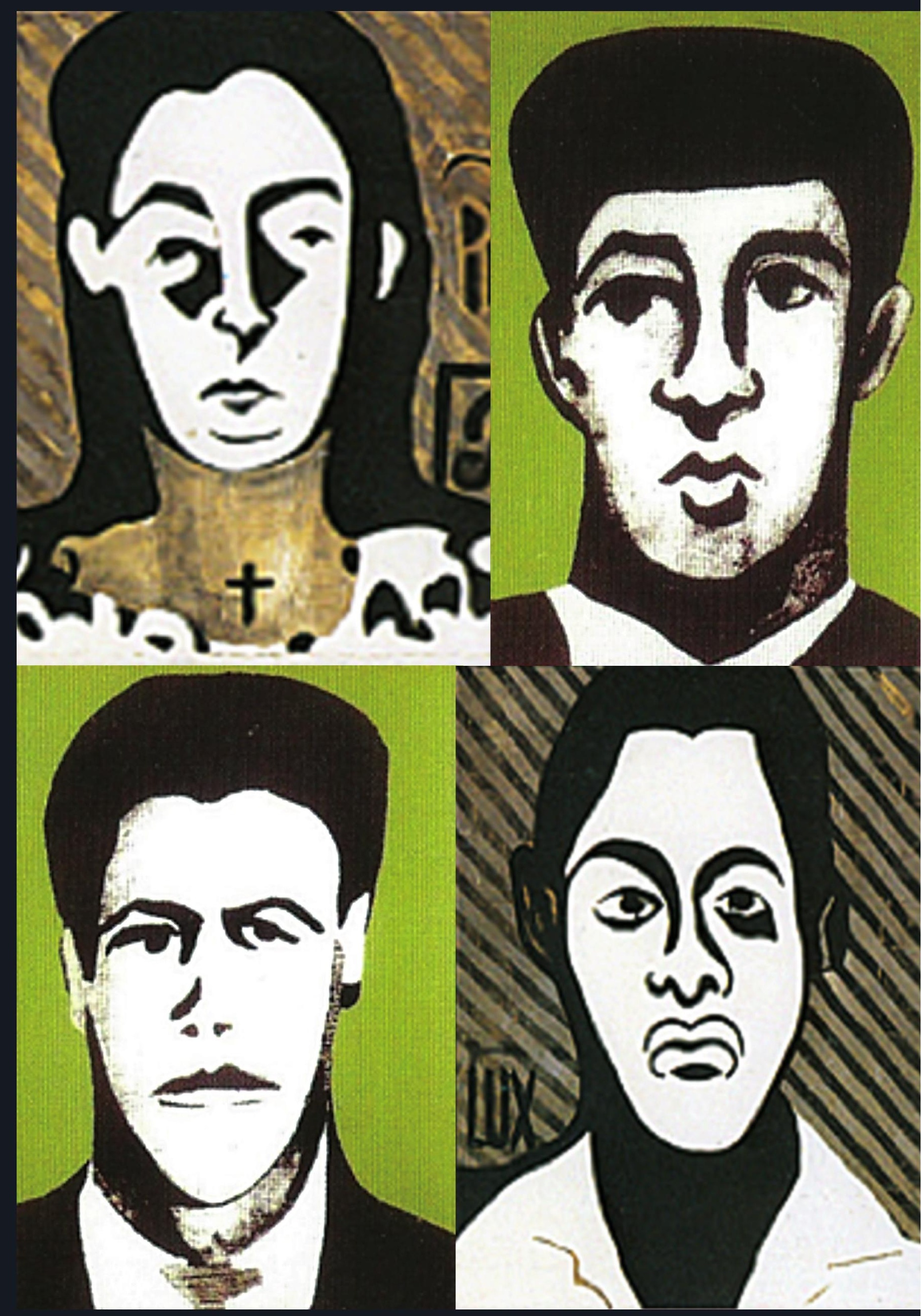




\section{Lutas e \\ tensões \\ nas obras \\ de Rubens \\ Gerchman}

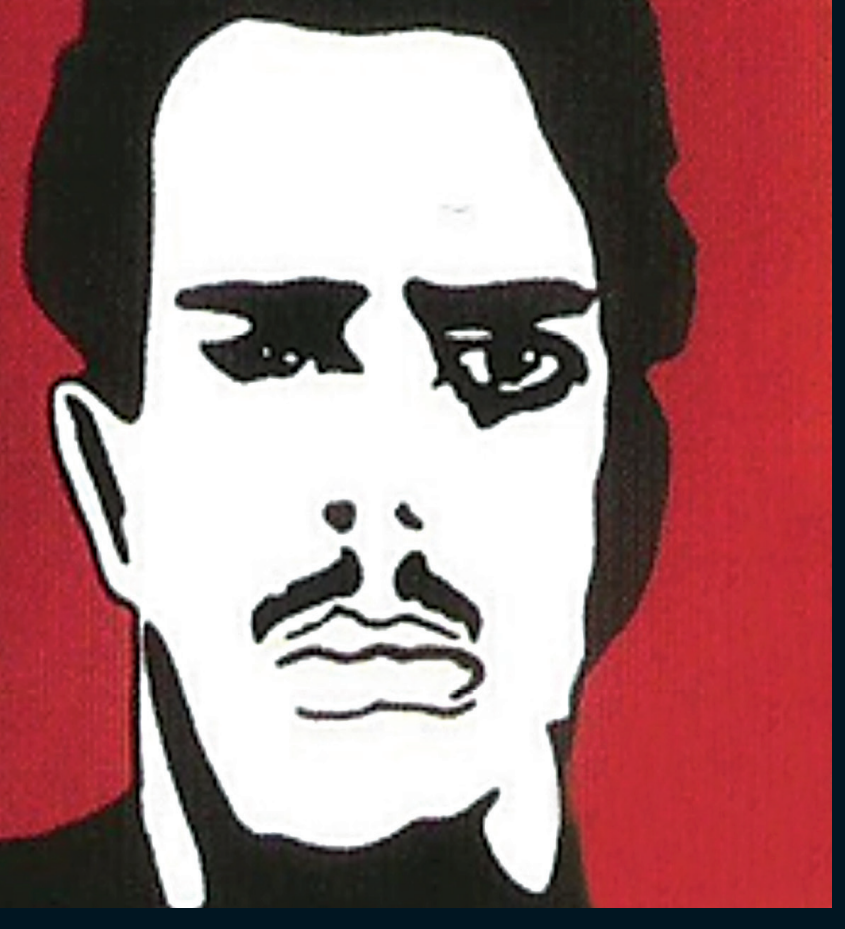

Simone Rocha de Abreu
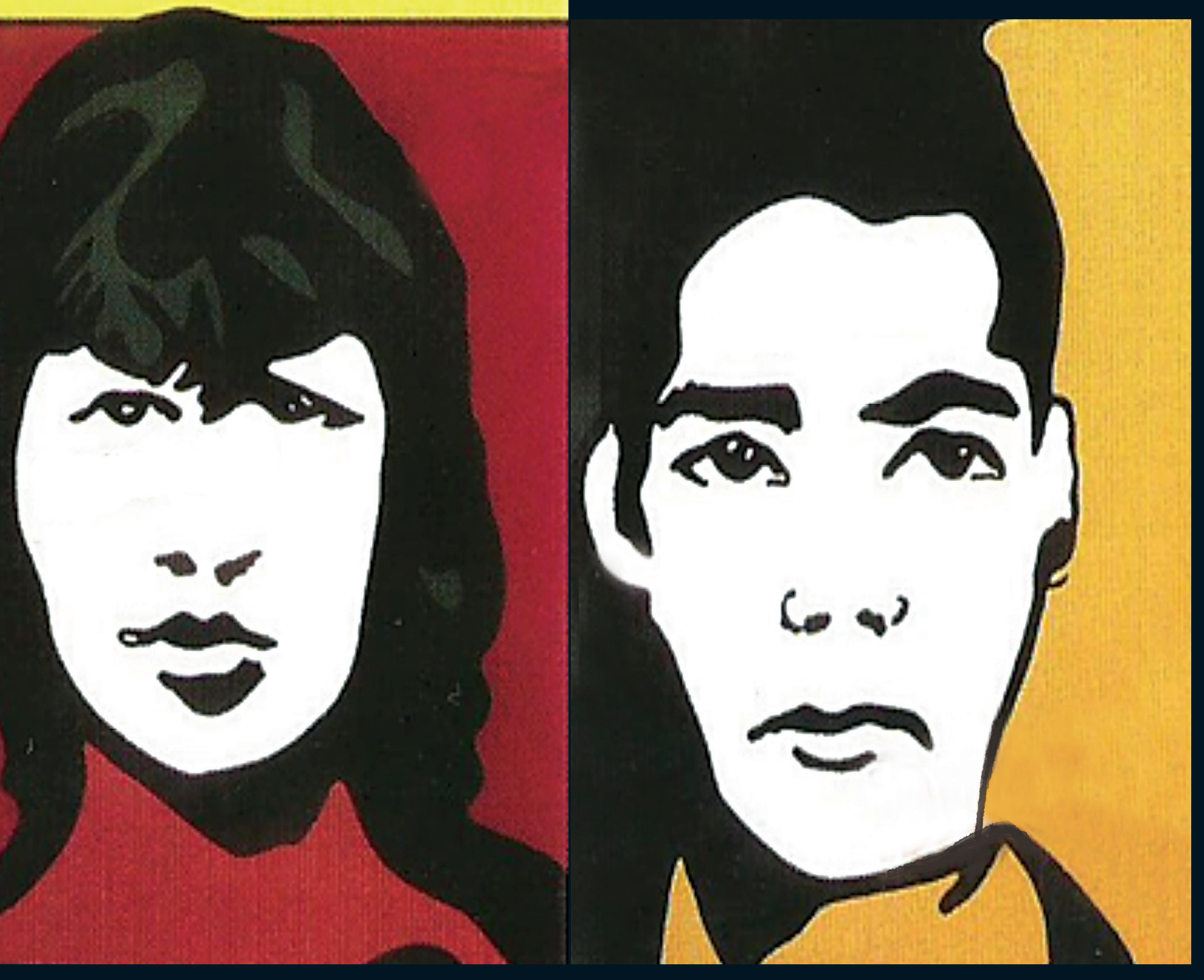


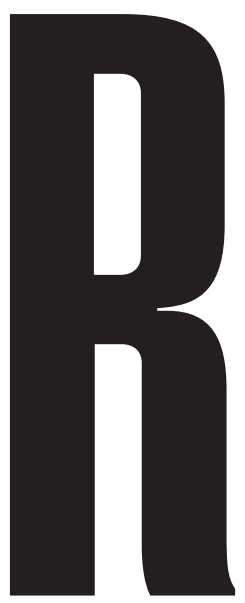

ubens Gerchman ${ }^{1}$ investigou na sua obra a sua identidade muitas vezes vista pelo artista como dual, resultado da versatilidade dos diferentes olhares e da simultaneidade de situações que vivenciou desde a infância, entre o ambiente familiar e o entorno de sua casa no Rio de Janeiro.

Filho de imigrantes judeus ucranianos, que, ao entrar no Brasil, tiveram a grafia de seu sobrenome alterada de Gerchman para Hershmann, Rubens, que era originalmente Reuben, viveu em uma família que encontrou na tipologia um ofício. O pai e o tio do artista trabalhavam com as letras, a impressão e a publicidade. Desde cedo, povoaram a imaginação do artista a duplicidade do seu nome, do nome da família e a multiplicidade de culturas. $\mathrm{O}$ artista refletiu sobre essa multiplicidade, sobre as situações duais, sobre a diversidade e também o particular, e esse conjunto de preocupações influenciou a sua produção. Refletindo sobre a sua identidade, ele realizou as obras: Sou 1566166 Logo

1 Rubens Gerchman nasceu no Rio de Janeiro em 1942 e faleceu em São Paulo em 2008.
Existo, 1966 (Figura 1) e Dupla Identidade, 1994 (Figura 2).

Dupla Identidade é o título de um álbum litográfico no qual Gerchman revisita a história da família e dos seus antecedentes. O mote para essa produção é uma coleção de documentos da família que ele recebeu de uma tia. A partir disso, investigou a dupla personalidade dessas pessoas que deixaram seus lugares e assumiram novas vidas, novas relações de amizade, novos nomes, novas identidades, novos números e carimbos, se casaram nessa nova realidade e formaram família.

Além da identidade individual, Rubens Gerchman também investigou a identidade do homem massificado na cidade grande, caótica e fragmentada. Enquanto Hélio Oiticica fazia os Parangolés, Glauber Rocha realizava Terra em Transe, Lygia Clark fazia as Máscaras Sensoriais, Antônio Dias realizava a série de pinturas sobre a violência, empregando o branco, preto e vermelho em uma sucessão aparentemente desconexa de quadros,

SIMONE ROCHA DE ABREU é professora da Universidade Federal da Integração Latino-Americana, crítica de arte e membro da Associação Brasileira de Críticos de Arte e do Fórum Permanente de Arte e Cultura da América Latina. 


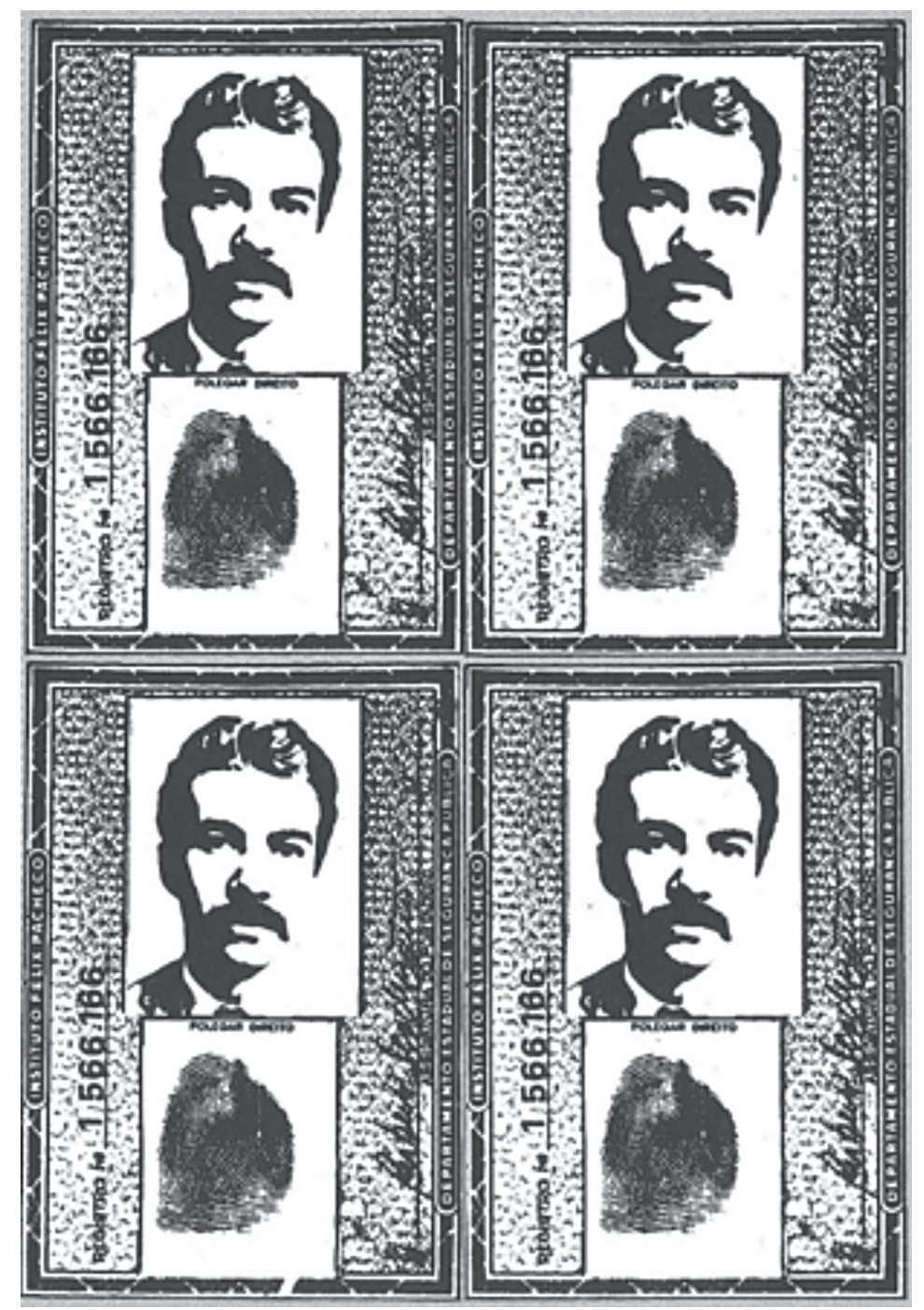

Figura 1.

Sou 1566166 Logo Existo, 1966, serigrafia.

Obra pertencente ao álbum Felix Pacheco,

realizado com Carlos Scliar

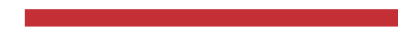


Gerchman pintava a realidade que percebia, ou seja, a multidão, o indivíduo solitário e anônimo na cidade grande, e os sentimentos desses indivíduos, as suas condições de vida.

Também explorava os pares complementares nessas lutas e tensões, entre os quais o mais recorrente foram o homem e a mulher, empregando a imagem positiva e negativa do perfil humano. No caminhar de sua pesquisa plástica, essa luta e tensão entre o homem e a mulher culminaram nos intensos beijos, expressão da fusão entre os contrários (Figura 3).

A fusão homem-mulher também foi explorada pelo artista em uma outra série de fotopinturas realizada a partir de fotografias do templo de Kajurao, na Índia. O artista viajou duas vezes para esse país, entre 2000 e 2001, mas somente em 2007 retrabalhou as suas tomadas fotográficas, que privilegiaram as colunas e fachadas do templo, repletas de esculturas eróticas feitas em pedra e terracota. Nelas, a temática erótica está representada sem nenhuma conotação profana, muito pelo contrário, pois o sexo na religião hindu não se opõe à religião, sendo considerado como uma forma possível para se alcançar a elevação do espírito.

Gerchman interferiu nessas tomadas fotográficas atribuindo às formas cores e texturas, e assim destacando as inúmeras poses eróticas, conferindo conotações subjetivas, como o caráter avermelhado nas bochechas das personagens em plena atividade sexual. Também destacou lábios vermelhos e partes das cenas que antes não eram completamente perceptíveis em terracota ou pedra, pois a cor era praticamente uniforme. Sendo assim, podemos dizer que Gerchman, com suas interferências de cores e texturas, aumentou o potencial erótico dessas imagens.
Como representante da cultura judaico-cristã, o artista devolve ao erotismo estampado no templo hindu o caráter profano (Figura 4). Esse dado é ainda mais potencializado quando insere algumas dessas fotopinturas em caixas de pequenos formatos, conferindo um caráter íntimo, privado e particular, transformando o espectador em um voyeur, que espia o que não deve, bem distante dos propósitos da imagem original, ou seja, as esculturas da fachada do templo hindu.

\section{DENÚNCIA DA OPRESSÃO: O HOMEM ANÔNIMO}

\author{
"A realidade coletiva, a solidão \\ individual, isso me preocupa. \\ Leio muito jornal, é onde eu recolho \\ a maior parte de meu material de \\ trabalho" (Gerchman)².
}

Gerchman denunciou em suas pinturas diversas formas de violência ao homem urbano massificado e torturado pelas tiranias da propaganda, que geram desejos por itens de consumo, por sair do anonimato, por sair da "caixa de morar", da "caixa de origem", das "caixas" todas que o aprisionam.

A fotografia do artista entre manequins (Figura 5) revela a preocupação de Gerchman pela condição de anonimato imposta às pessoas nas aglomerações humanas, como as das grandes cidades. É a preocupação com relação ao homem massificado e a consequente perda das suas características específicas, tal como se vê na obra Desaparecidos João da Silva $n^{o} 1$ e João da Silva $n^{\circ} 2$ (Figura 6).

2 No filme Ver Ouvir (Fontoura, 1966). 


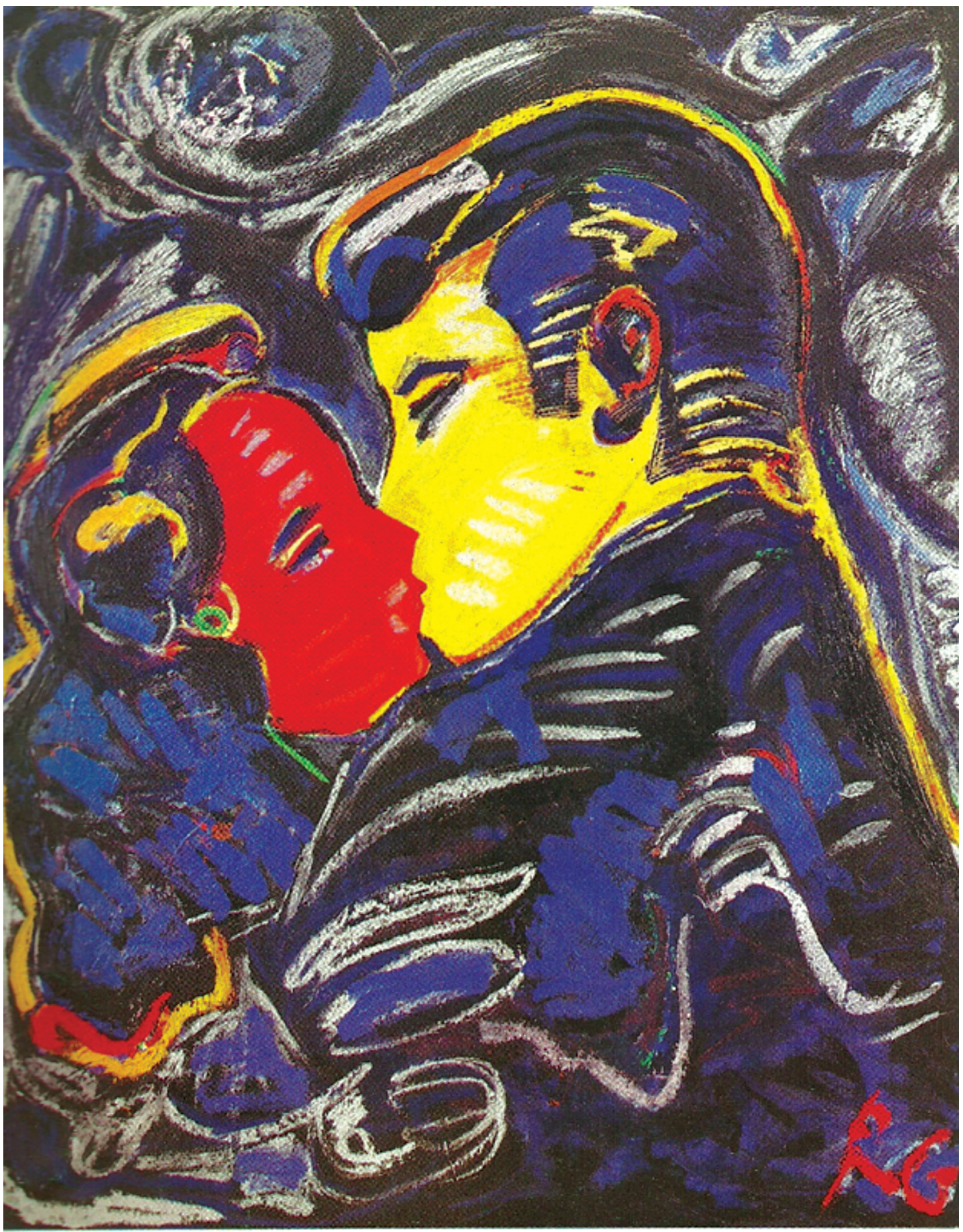

Figura 3. Noctum Couple, 1993, acrílico e óleo s/tela, 140x112cm 


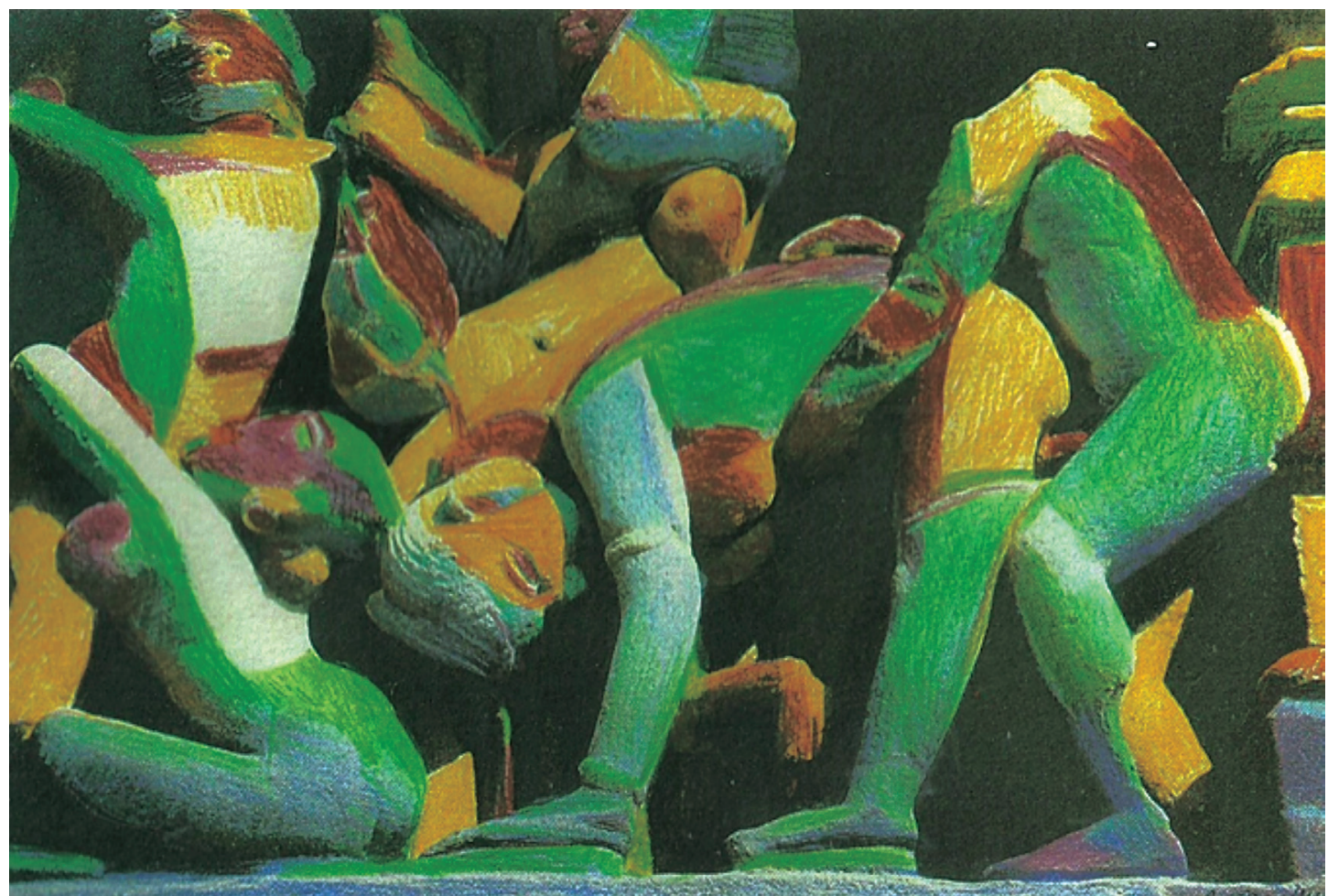

Figura 4. Da série Eros e Tânatos, 2007, fotopintura, 31×35cm

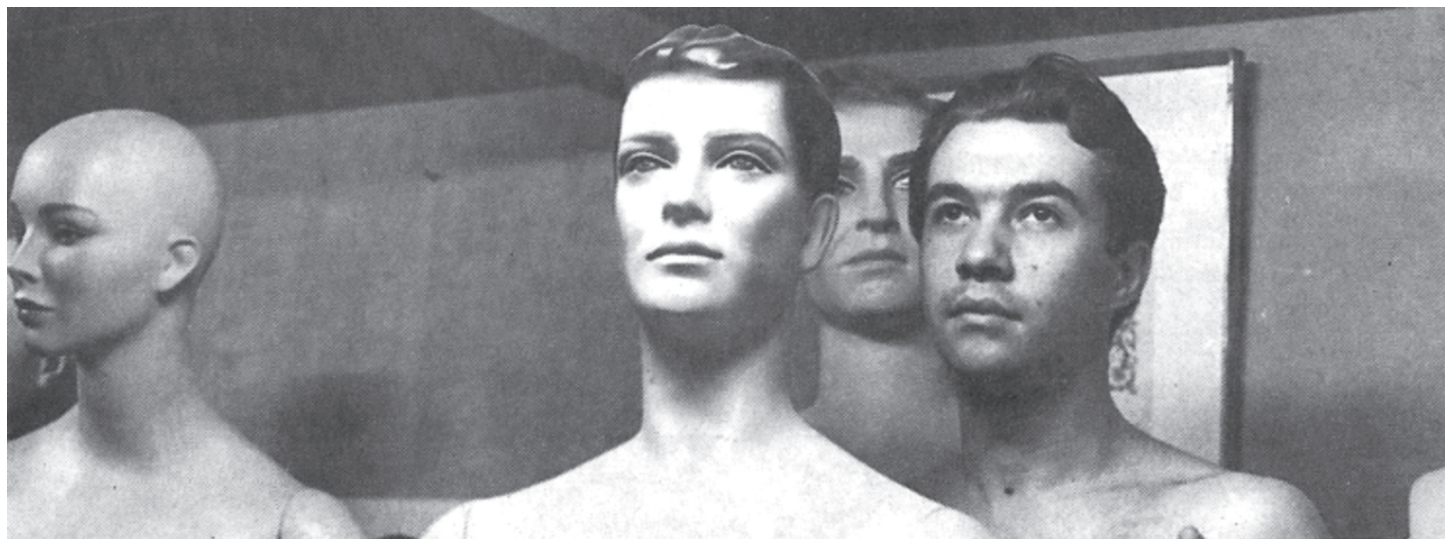

Figura 5. Gerchman entre manequins, 1965. Fotografia de Walter Firmo

Nela o artista reforça a ausência dos rostos pelo vazio representado pela não coloração adicionada à tela na face e também por um grau de esvanecimento da imagem. Parecem dois homens fantasmas ou vultos de pessoas que poderiam estar realmente ali. São ausentes de especificidade, e essa condição de ser parte de um todo muito maior é reforçada pelas descrições junto às personagens.

Com o mesmo tratamento visual, Gerchman denunciou outro tipo de opressão, fruto da exploração dos desejos. Trata-se de Carnet Fartura (também chamada de Casal Fartura - Figura 7), obra exposta em Opi- 


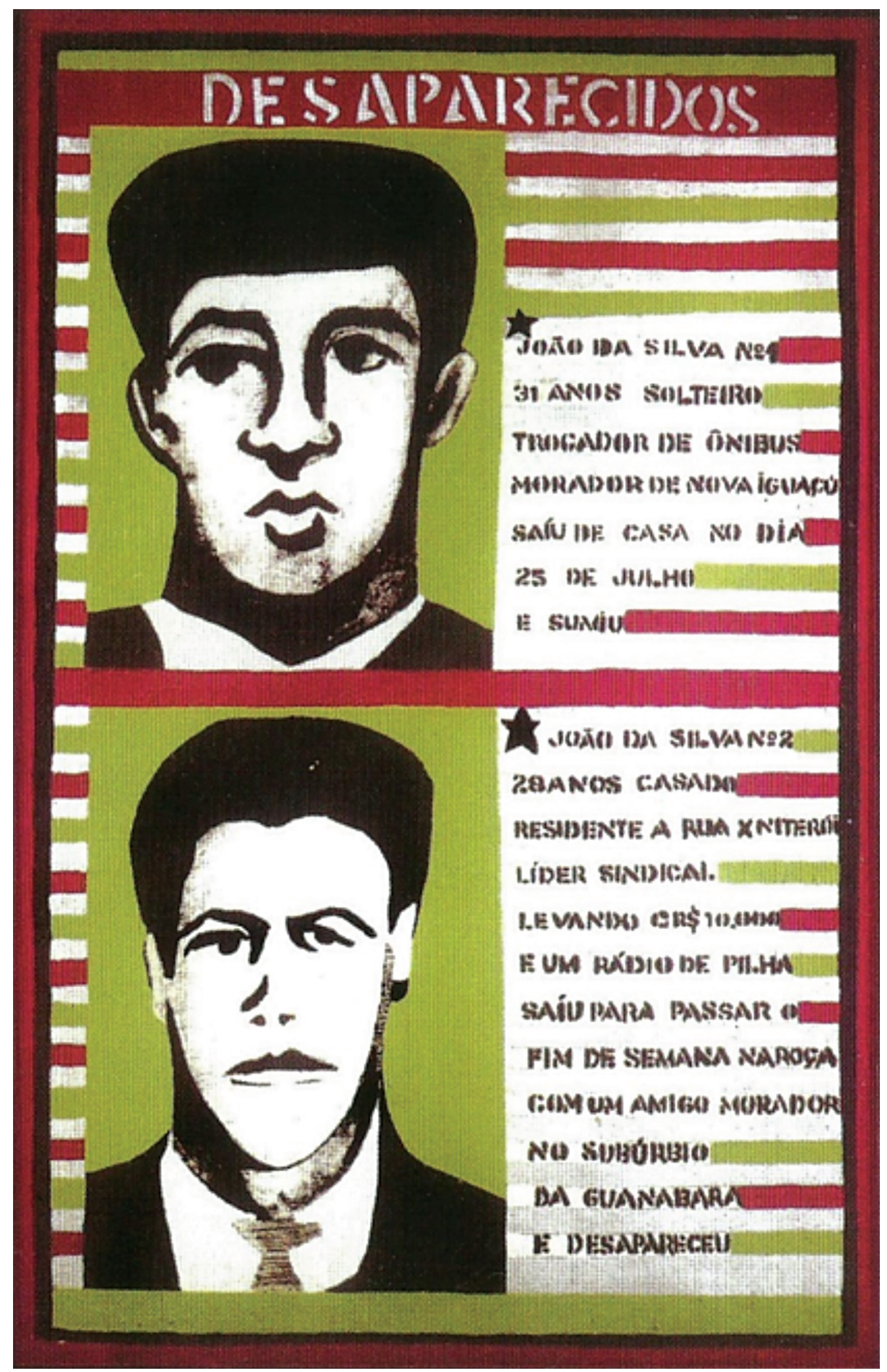

Figura 6. Desaparecidos João da Silva no 1 e João da Silva no 2 ,

1965, acrílico sobre madeira, $120 \times 40 \mathrm{~cm}$ 
nião 65 (no MAM-RJ). O desejo enfocado é o de ganhar facilidades e, assim, "comer e morar um ano de graça com toda a família". Algo tão trivial e que representa o sonho de homens e mulheres tais como os personagens da obra, alvos desta ideia vendida por uma sociedade voraz pelo consumo.

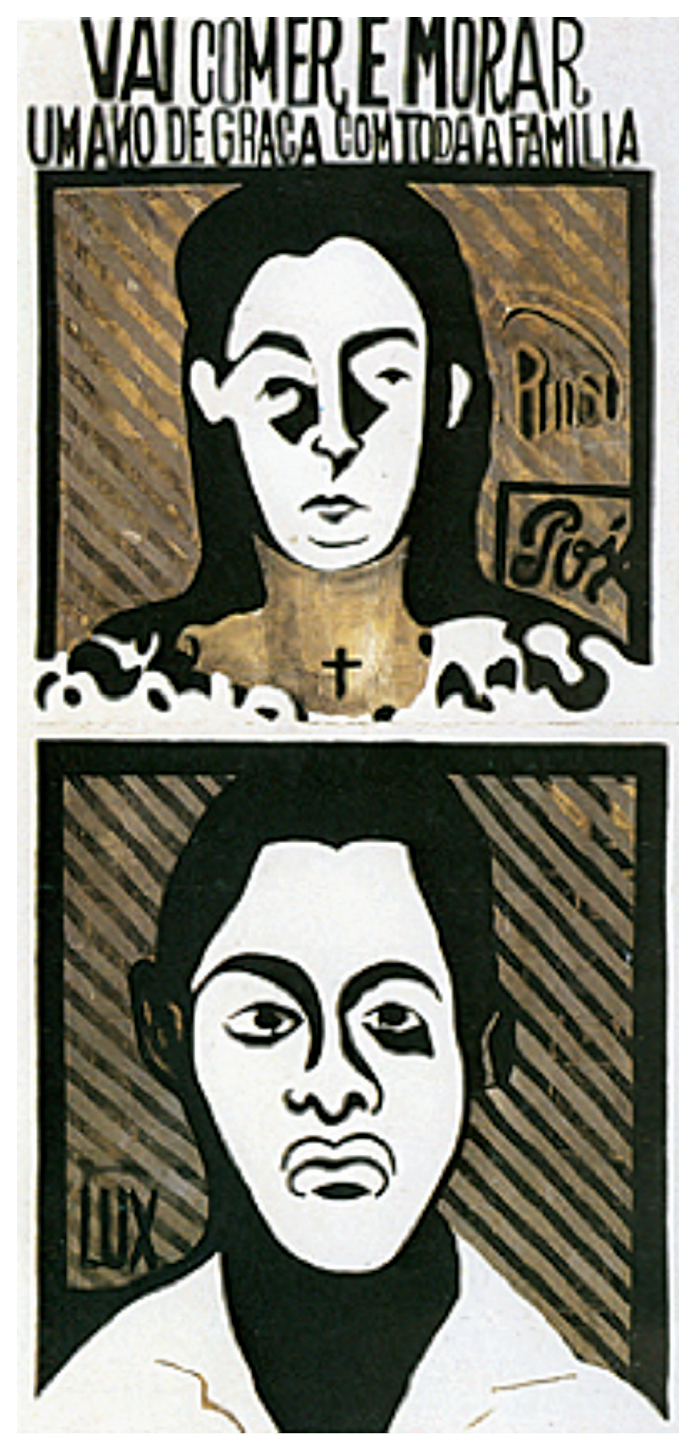

Figura 7. Carnet Fartura, 1965, acrílico sobre tela, $210 \times 120 \mathrm{~cm}$

Outra obra de Gerchman que também trabalha a questão da violência ao homem massificado pela imposição de ideias prontas, ditadas por outrem e, portanto, sem origem no anseio próprio, é Assegure Seu Futuro - Ganhar Mais e Viver Melhor (Figura 8), de $1968^{3}$. Nessa obra, o artista trabalha a imposição de ideias que homogeneíza a todos, somente resguardando a diferença entre homens e mulheres quando estabelece as diferenças entre profissões.

A obra a seguir, denominada Os Desaparecidos 1970/79 (Figura 9), reúne nove quadros e estabelece uma associação dois a dois com fatos ocorridos no futebol e na situação política do Brasil. Uma foto de 1969 mostrando presos políticos libertados na frente do avião que os levaria ao exílio (Figura 10) é comparada à foto de um time de futebol em posição usual. No outro par comparativo aparecem as silhuetas dos personagens como se costuma fazer para identificar as pessoas em uma foto documental, mas os nomes não estão colocados. No último par de imagens, o artista comparou uma foto de um anistiado sendo carregado e recebido de maneira festiva à comemoração da vitória alcançada pelo time de futebol representado por um jogador. Em ambos os retratados se destaca a atitude de júbilo.

Entre 1962 e 1963, Rubens Gerchman trabalhou como diagramador da revista Sétimo Céu, da Editora Manchete. Nesse trabalho teve acesso a uma grande quantidade de material gráfico a ser divulgado com grande circulação, como horóscopos, correios sentimentais, fotonovelas, etc. Dessa experiência formou-se o gosto pelo caráter gráfico, que é observável em sua obra pelo contorno bem

3 Fábio Magalhães (2006), no entanto, indica o ano de 1967. Optou-se por 1968 por ser a data atribuída no catálogo Gerchman, editado em 2007 pela Portfolio Brasil, no qual o artista trabalhou. 


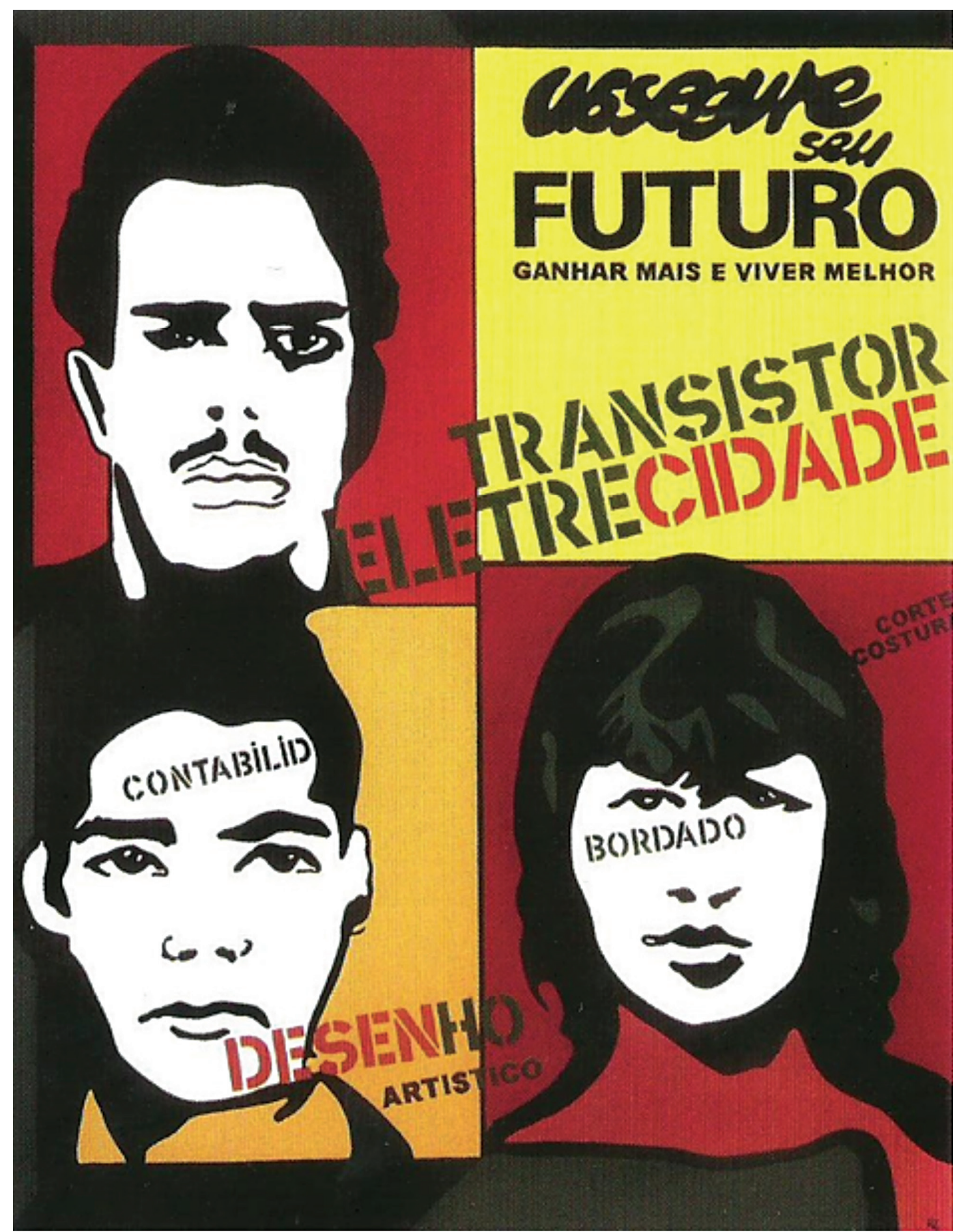

Figura 8. Assegure Seu Futuro - Ganhar Mais e Viver Melhor, 1968, 95x120 cm 


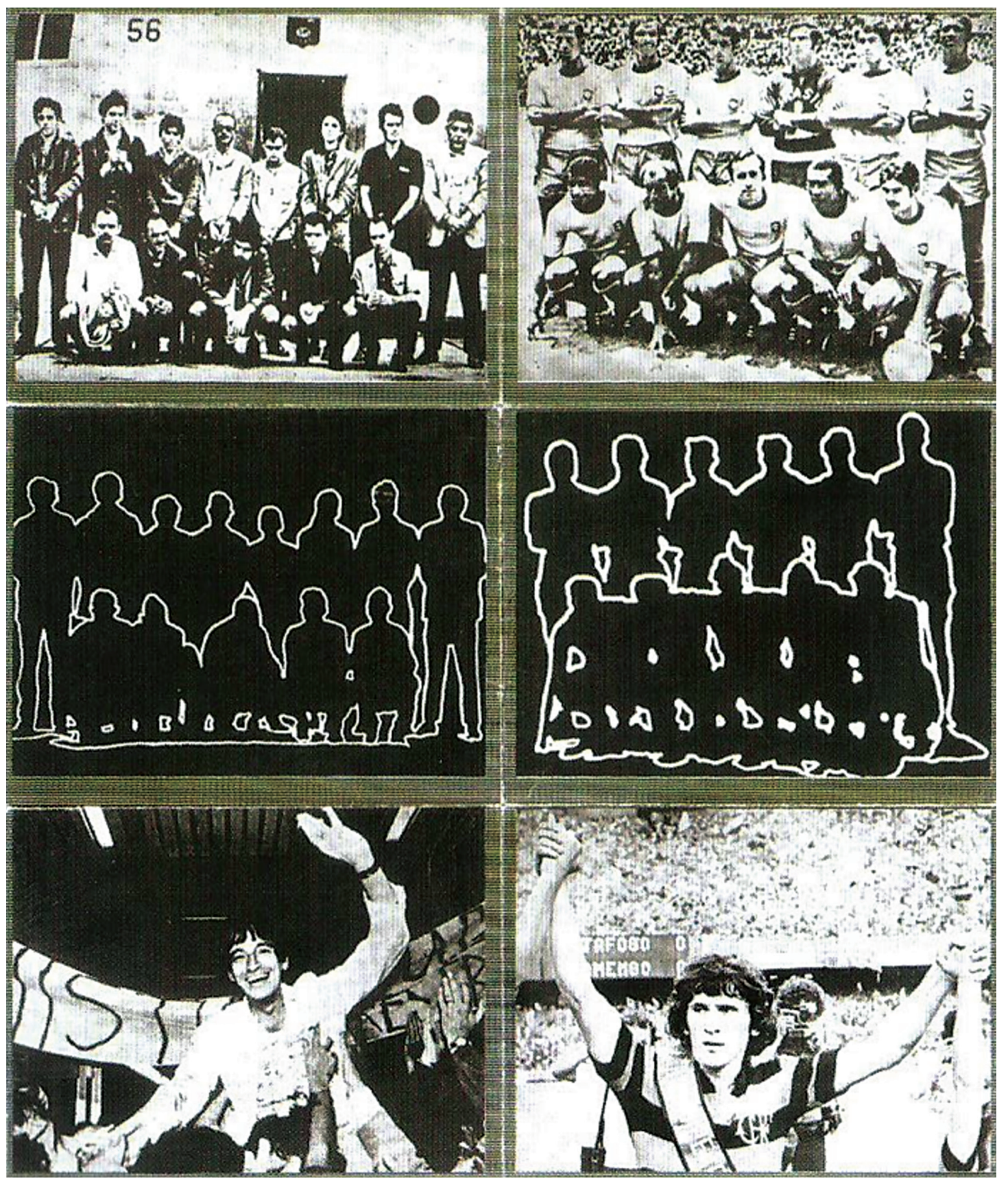

Figura 9. Os Desaparecidos, 1970/79 


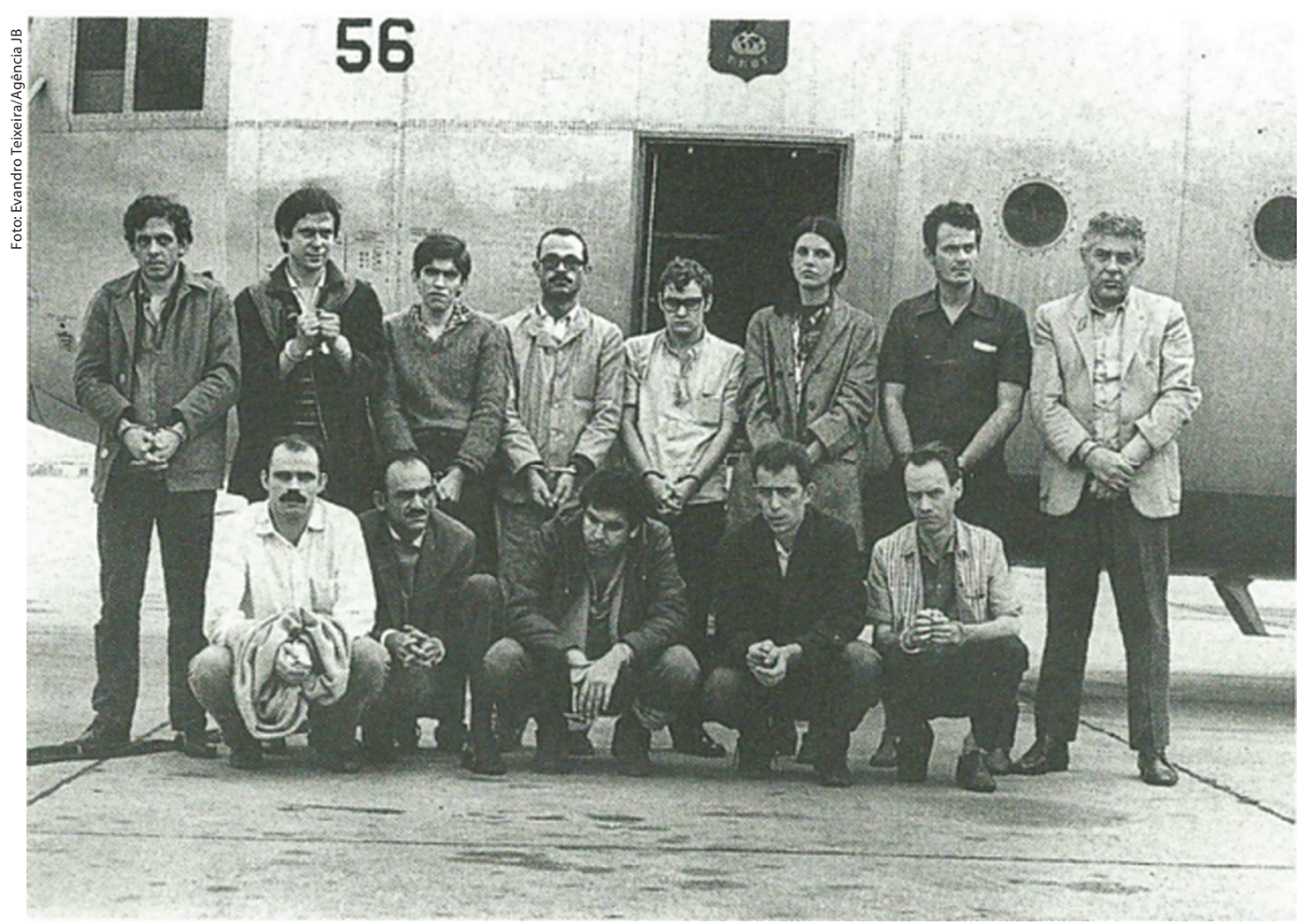

Figura 10. Prisioneiros políticos prontos para serem banidos do Brasil, em troca do embaixador sequestrado dos EUA, 1969

definido e o preenchimento das formas com cores uniformes. $\mathrm{O}$ tratamento gráfico que o artista emprega é uma metáfora do homem urbano que consome a cultura de massa e se mantém alheio aos problemas do país.

A realidade brasileira não escapou à produção artística de Rubens Gerchman, como pode ser visto em $O$ Futebol: Flamengo Campeão (Figura 11), de 1965. Nesta obra o artista pintou a solidão em meio à multidão desorientada acotovelando-se no estádio durante um jogo de futebol do Flamengo como uma síntese da diversão popular de sua cidade. Pintou o sonho de riqueza em Carnet Fartura (Figura 7) e assim a possibilidade de se isentar de preocupações diárias de suprir necessidades básicas. Pintou o sonho de muitas meninas de saírem do anonimato ao serem eleitas misses. Pintou também as Marias como "as virgens de lábios de mel" (Figura 12), para depois que os sonhos acabassem.

No filme Ver Ouvir (Fontoura, 1966), há um segmento intitulado "Rubens Gerchman: os desconhecidos" em que o narrador é o próprio artista abordando a sua produção e as motivações para tal. Em grande parte da filmagem, a câmera registra o impacto das obras do artista nas ruas. É, portanto, o homem comum, massificado e sujeito das suas preocupações que é filmado e interpelado sobre o que acha das obras. Outras cenas mostram as obras de Gerchman na rua, em meio à cidade, sendo assim devolvidas à cena urbana que as gerou. Ainda outras cenas mostram sínteses importantes 


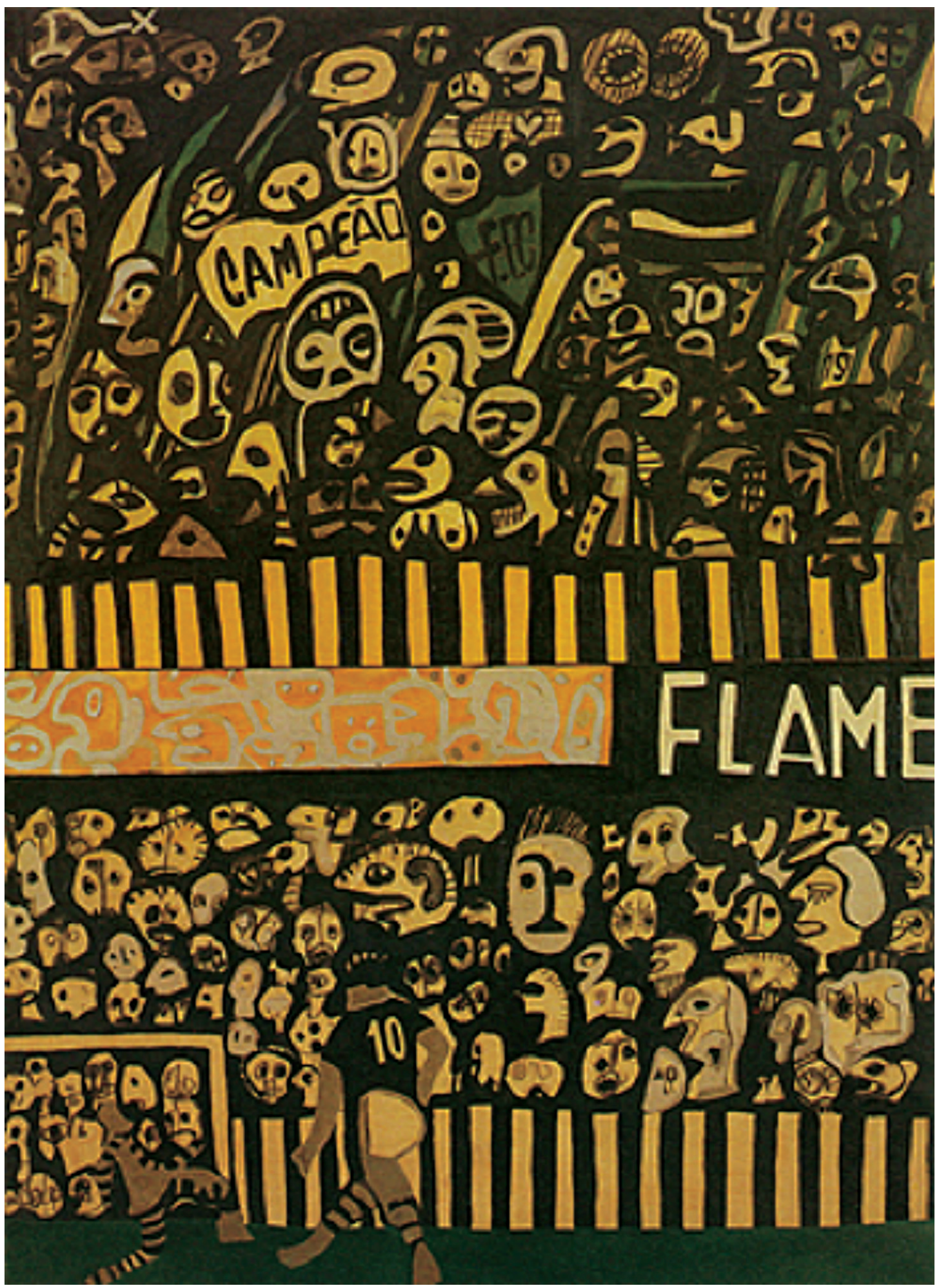

Figura 11. O Futebol: Flamengo Campeão, 1965, tinta acrílica sobre eucatex, 244x122 cm 


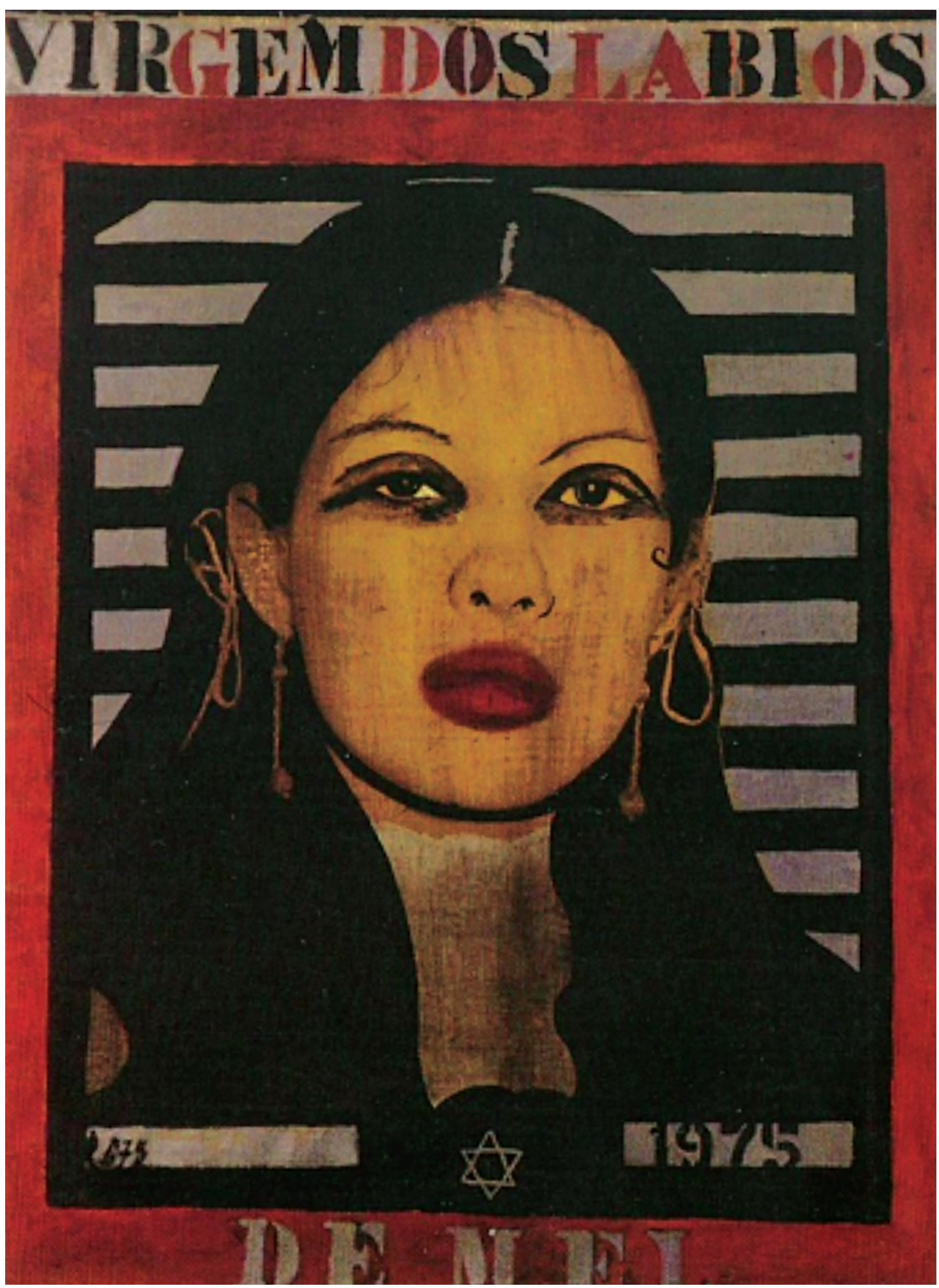

Figura 12. Lou, Virgem dos Lábios de Mel, 1975 
da produção artística de Gerchman, tais como o artista ao lado de uma banca de jornal, uma vitrine focando os inúmeros manequins, todos iguais e sem expressão facial. Também aparecem anônimos levando na mão os seus documentos de identidade. Entre outros sons e músicas que compõem a trilha sonora, ouve-se a canção "Sentimental Demais", de Altemar Dutra, para reforçar o ambiente do homem comum e massificado que preocupa o artista.

\section{A SÉRIE CAIXA-MUNDO QUE APRISIONA 0 HOMEM}

Outro depoimento importante dado por Gerchman em Ver Ouvir é sobre a série chamada Caixas de Morar. Segundo o artista, o mundo é uma caixa na qual mora o homem e a caixa é o seu limite: "Esse homem limitado pelas grandes verdades fabricadas, homem a quem a realidade assusta tanto que como solução só resta desaparecer". Enquadrado dentro dos limites impostos por outros, o homem desaparece, alienando-se, perdendo-se de si.

\section{E A PALAVRA EXPLODE COMO OBRA}

A palavra fez muitas vezes parte da obra de Gerchman. Nos trabalhos reunidos sob o título Cartilha no Superlativo, elas aparecem como potência central. Esta "cartilha" reúne as obras Lute, Ar, Terra, Sol, SOS. Em Lute (Figura 15), Gerchman impõe ao espectador a sua palavra-objeto-cor, para a construção de uma ideia a ser difundida em espaço de grande circulação. O artista pretendia que essa obra fosse exposta na rua, a palavra-objeto-cor atravessaria a Avenida Rio
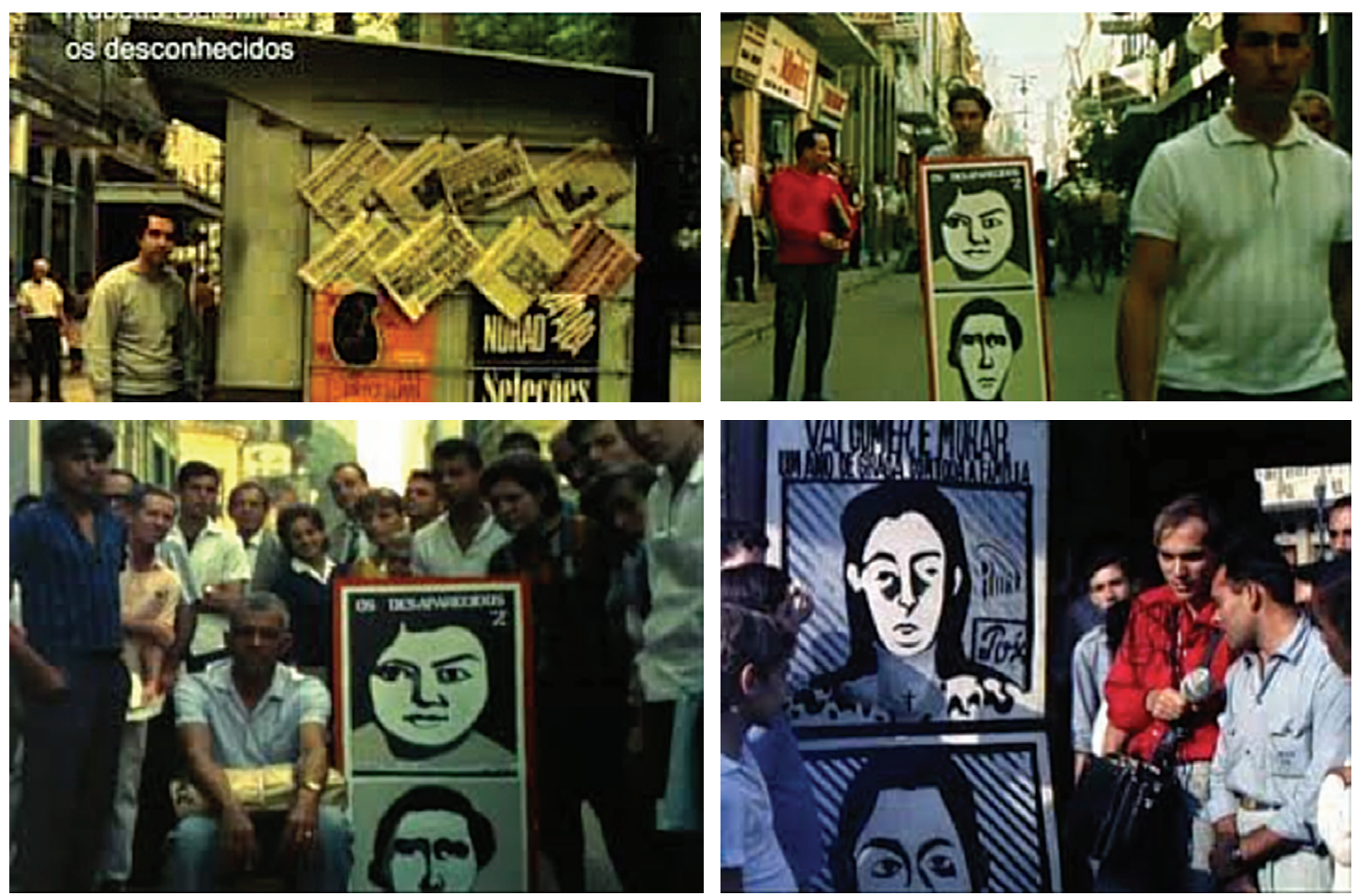

Figura 13. Alguns frames do filme Ver Ouvir, 1966 


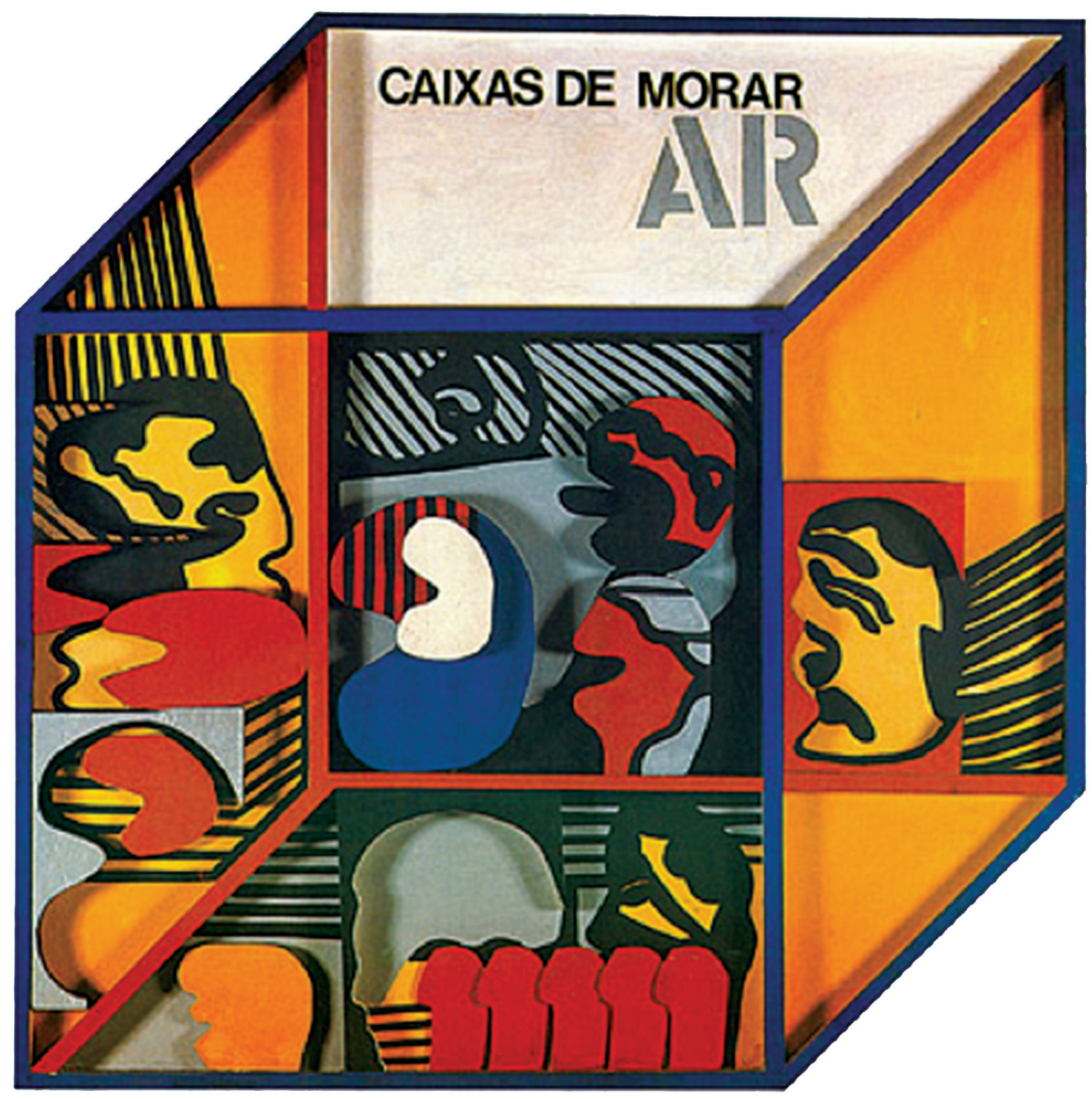

Figura 14. Caixas de Morar - Ar, 1966, relevos de madeira pintados com tinta acrílica, $120 \times 120 \mathrm{~cm}$

Branco, no Rio de Janeiro, impondo fisicamente a mensagem a quem por ali passasse.

A ideia era revitalizar o significado das palavras, que estavam desgastadas naquele momento de regime autoritário e, assim, com esta "nova cartilha", o artista buscava revigorá-las, ou seja, devolver o significado original a elas. Percebe-se, portanto, a intenção de promover o senso crítico sobre a situação política do país e suas consequências para o indivíduo.
Entre 1968 e 1972, Gerchman morou em Nova York, onde desenvolveu inúmeras obras em que a palavra é o elemento central. Destacamos aqui as obras $\operatorname{Ar}$ (Figura 16) e Men Women (Figura17), que compõem a já mencionada série Cartilha no Superlativo. Essas obras, muitas vezes, eram associações de palavras-ideias que desvelavam novos sentidos, como em Men Women, em que a justaposição das palavras e a oposição das cores evidencia a tensão e complementaridade do 


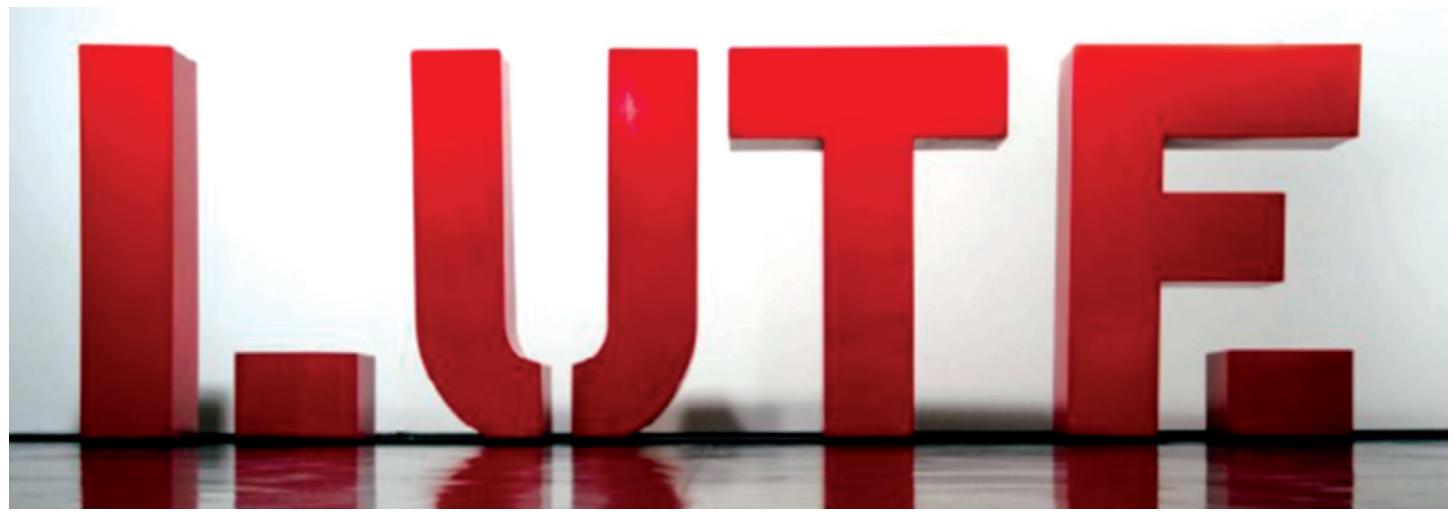

Figura 15. Lute, da série Cartilha no Superlativo, 1967

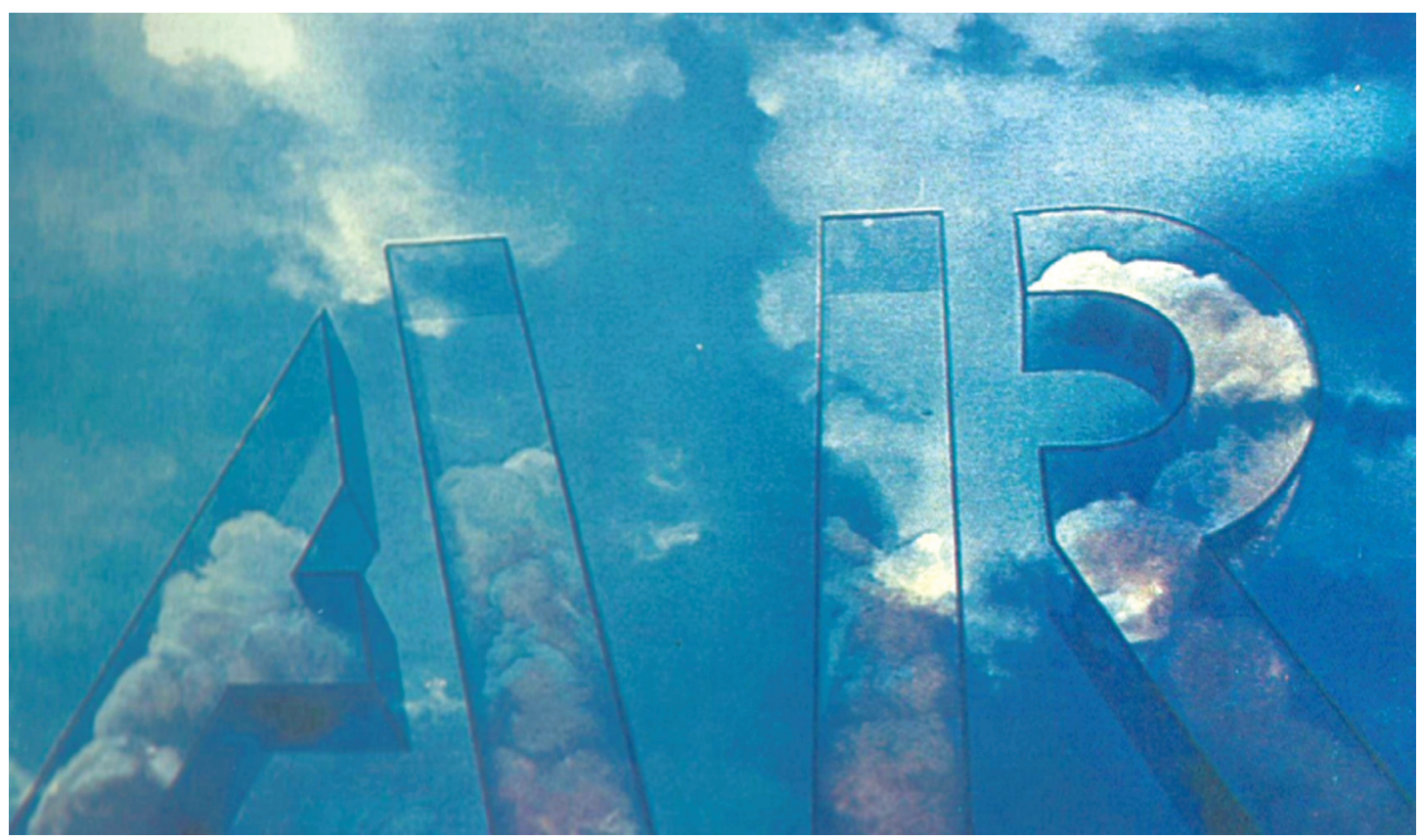

Figura 16. Ar, 1971, acrílico e algodão, registro sobre papel, $70 \times 50$ cm

par de opostos representado pelo homem e pela mulher. Já na versão da obra $A r$, reproduzida neste artigo, o artista associa a imagem do céu a um objeto de acrílico no formato da palavra "ar" parcialmente preenchido por falsas nuvens de algodão, associando, portanto, a representação escrita ao real e, assim, devolvendo a palavra ao seu significado.

Ao retornar ao Brasil, o artista realizou uma retrospectiva de suas obras no Museu de Arte de São Paulo Assis Chateaubriand, com curadoria de Lina Bo Bardi, onde essa produção centrada na palavra obteve destaque curatorial, como se pode ver na Figura 18.

\section{TENSÃO: HOMEM E MULHER}

Diversas obras de Gerchman, como Men Women e as da série Caixas de Morar, apresentam o par de opostos homem-mulher. 


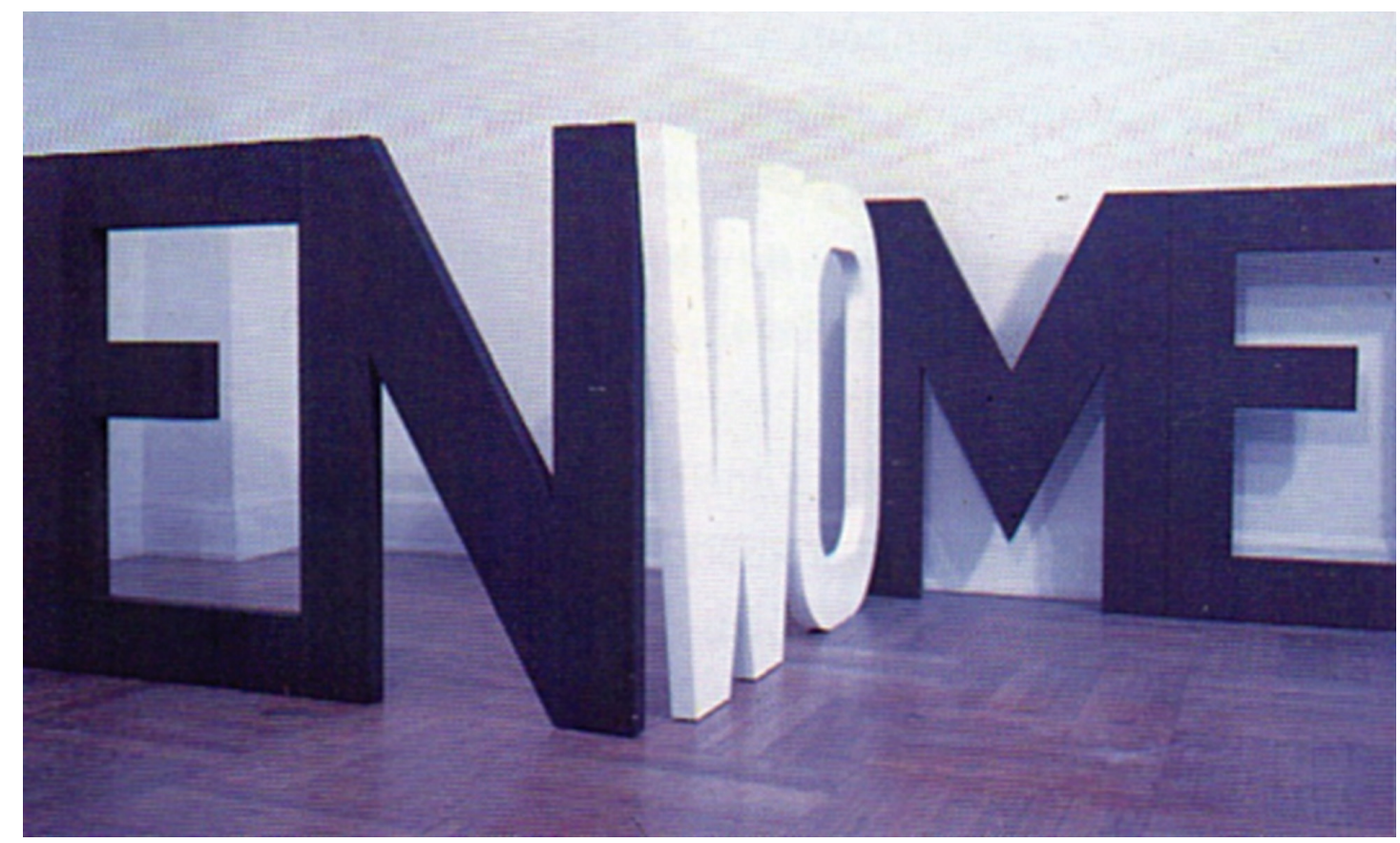

Figura 17. Men Women, 1971, escultura em madeira pintada

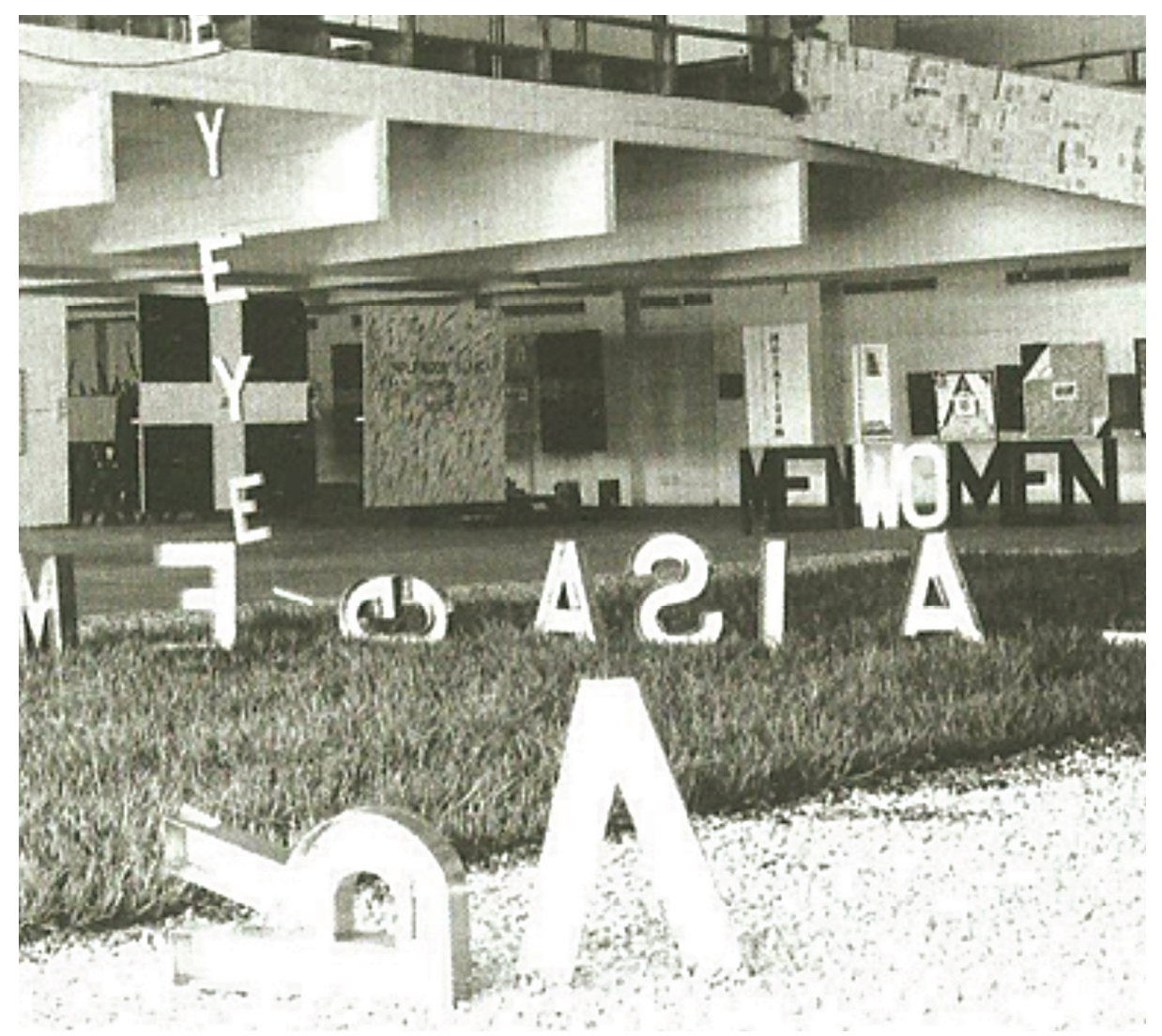

Figura 18. Exposição Rubens Gerchman no Masp, 1974, com curadoria de Lina Bo Bardi 
As "caixas de morar" apresentam o signo da multidão, os desenhos negativos das faces de homens e mulheres, bem como uma síntese do rosto na multidão, que vai se repetir muitas vezes em sua obra e que lembra a letra "c". Este signo aparece em positivo e negativo, sendo relevante perceber que a síntese da face na multidão é feita mencionando a boca, que toma proporções enormes, causando o barulho na caixa-mundo. Outro destaque são os símbolos do "mau gosto" presentes nessas obras
(Figura 19), tais como o do time de futebol, do porta-retrato com a expressão "amo-te" e da pintura no centro com papagaios, formando uma possível paisagem padronizada do Brasil.

\section{MAU GOSTO COMO ALEGORIA}

\section{DO HOMEM ANÔNIMO E SUBURBANO}

Gerchman alude ao mau gosto como alegoria do homem anônimo suburbano. Nesse

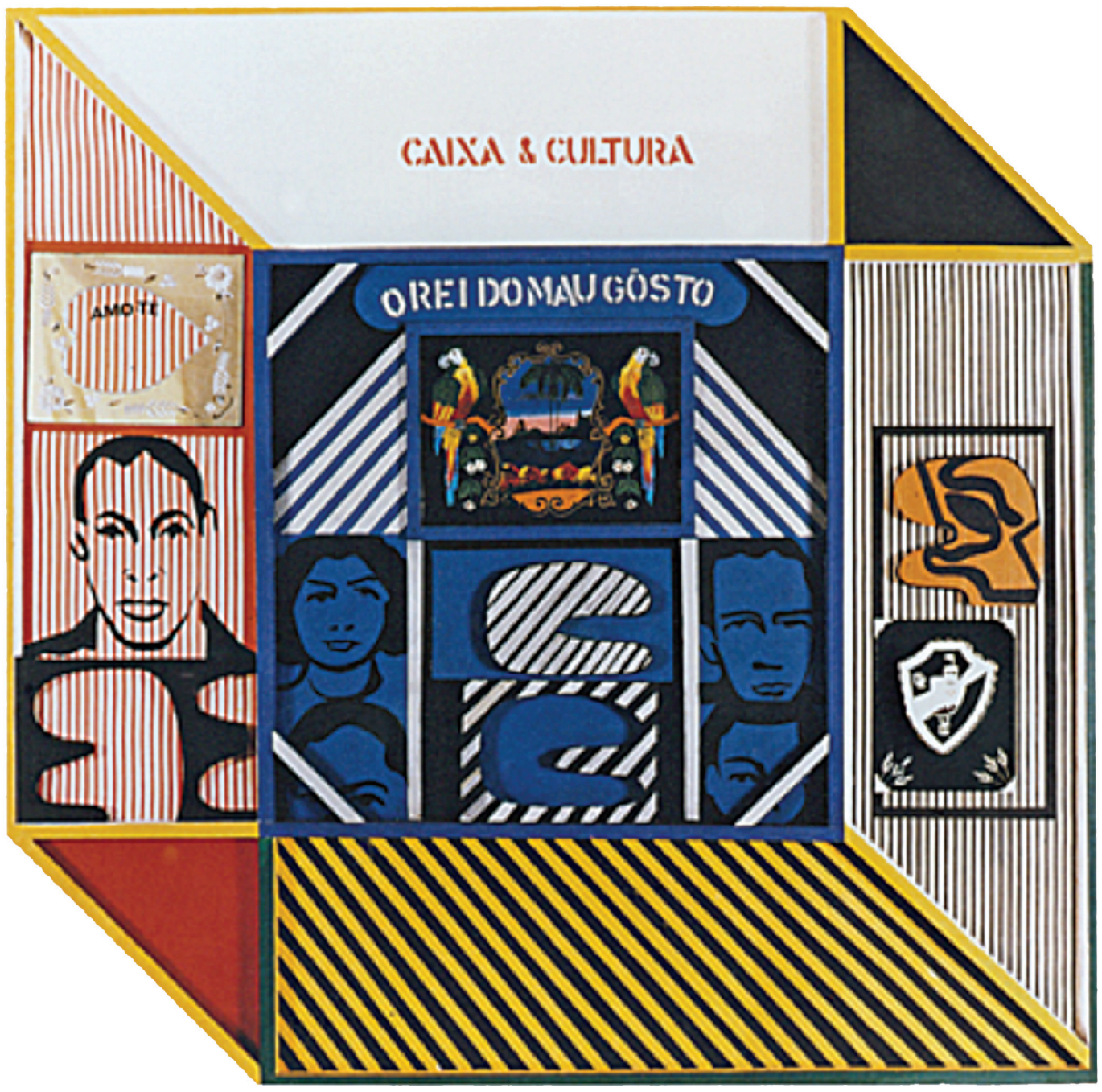

Figura 19. O Rei do Mau Gosto, 1966, relevos de madeira pintados

com tinta acrílica, colagem de espelho e asas de borboleta, $200 \times 200 \mathrm{~cm}$ 
sentido, está bastante sintonizado com o pensamento de Hélio Oiticica, que, ao falar da Tropicália, nos fala do "nascimento da imagem de uma nação" e da "descoberta de elementos criativos nas coisas consideradas cafonas":

"Tropicália = nascimento da imagem de uma nação: 'na verdade quis eu com TROPICÁLIA criar o 'mito da miscigenação'- somos negros, índios, brancos, tudo ao mesmo tempo...'. Quebra decisiva da ideia de 'bom gosto' e a 'descoberta de elementos criativos nas coisas consideradas cafonas" (Oiticica apud Salomão, 2003, p. 69).

Rubens Gerchman teve intensa relação de trocas sobre arte com diversos artistas, dentre eles, Hélio Oiticica, Lygia Clark, Antônio Dias, Roberto Magalhães e os músicos do Tropicalismo. Em referência a isso deve ser lembrada a composição de Caetano Veloso "Lindonéia", inspirada no quadro homônimo de Gerchman e cantada por Nara Leão no disco Tropicália ou Panis et Circencis. Gerchman, que realizou a capa do disco, dá o seguinte depoimento:

"A Lindonéia levou 25 anos para ser capa e musa do Tropicalismo. A capa do disco do Tropicalismo foi feita por mim: todos os artistas dentro de uma caixa de morar com uma fita verde e amarela. Escrito em letras também verde e amarelo lê-se: Panis et circencis. [...] A Lindonéia ganhou vida própria, virou música. Mário Pedrosa disse que ela era a Monalisa do subúrbio" (Gerchman apud Magalhães, 2006, p. 35).

Gerchman pontuou, ao longo de sua produção, lutas e tensões. $\mathrm{O}$ artista refletiu sobre essas situações e, ao fazê-lo, convocou o espectador de sua obra a se posicionar frente a elas. Luta política, luta contra a opressão social, em todas essas lutas Gerchman se mostrou resistente, recorrência necessária à utopia, ao sonho pelo estabelecimento de uma nova forma operante menos opressora, a um novo renascimento.

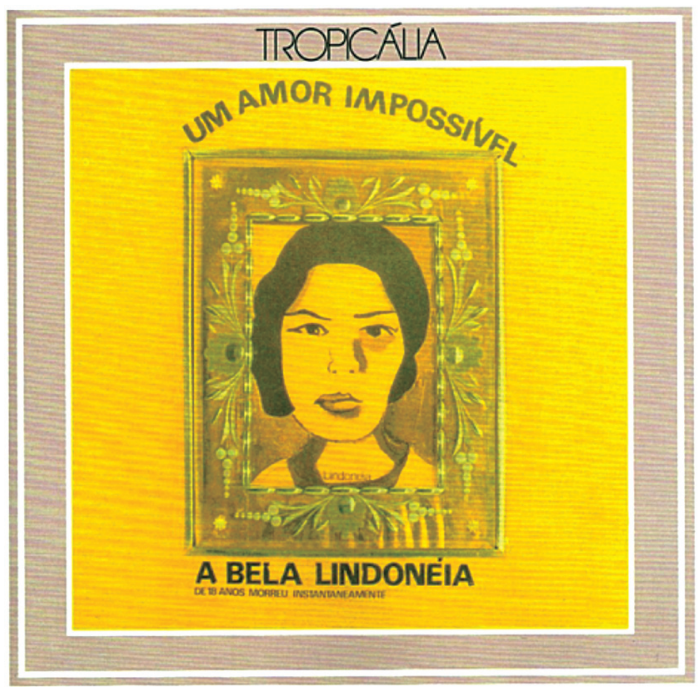

Figura 21. Capa do disco 25 Anos de Tropicália
Figura 20. Capa do disco Tropicália ou Panis et Circensis, 1966

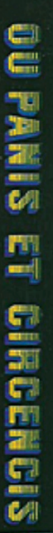




\section{BIBLIOGRAFIA}

ABREU, Simone Rocha de. Um Olhar sobre as Produções de Luis Felipe Noé, Antonio Berni, Rubens Gerchman e Antonio Henrique Amaral. Tese de doutoramento apresentada ao Programa de Pós-Graduação em Integração da América Latina da Universidade de São Paulo. São Paulo, Prolam-USP, 2014.

DUARTE, Paulo Sérgio. Anos 60: Transformações da Arte no Brasil. Rio de Janeiro, Campos Gerais, 1999.

ESCALLÓN, Ana Maria (org.). Gerchman. Rio de Janeiro, Gabinete de Arte do Rio de Janeiro, 1994.

FABRIS, Annateresa (org.). Arte \& Política: Algumas Possibilidades de Leitura.

São Paulo/Belo Horizonte, Fapesp/CArte, 1998.

GERCHMAN, R. Gerchman. Coleção Portfolio Brasil. São Paulo J.J. Carol, 2007.

JAREMTCHUK, D. "Experiências em Nova lorque na Década de 70", in Revista ARS, ano 6, v. 12. São Paulo, ECA-USP, 2008, pp. 104-13.

MAGALHÃES, Fábio. Rubens Gerchman. Coleção Arte de Bolso. São Paulo, Lazuli, 2006. MORAIS, Frederico. Artes Plásticas: A Crise da Hora Atual. Rio de Janeiro, Paz e Terra, 1975.

MURA, Cristina. Brasil dos Anos 60 e 70: Rubens Gerchman em Contexto. Dissertação de mestrado. São Paulo, ECA-USP, 2003.

MURAT, Rodrigo. Antonio Carlos Fontoura. Espelho da Alma. Coleção Aplauso, Cinema Brasil. São Paulo, Imprensa Oficial, 2008.

REIS, Paulo. Arte de Vanguarda no Brasil: Os Anos 60. Rio de Janeiro, Zahar, 2006. PECCININI DE ALVARADO, Daisy. Figurações Brasil Anos 60: Neofigurações Fantásticas e Neosurrealismo, Novo Realismo e Nova Objetividade. São Paulo, Itaú Cultural/Edusp, 1999.

SALOMÃO, Waly. Hélio Oiticica: Qual é o Parangolé? e Outros Escritos. Rio de Janeiro, Rocco, 2003.

\section{Catálogos}

APROXIMAÇÕES do Espírito Pop: 1963-1968. São Paulo, Museu de Arte Moderna de São Paulo, 2003.

GERCHMAN, R. Tempo: Rubens Gerchman. São Paulo, Ricardo Camargo Galeria, 2000. O Rei do Mau Gosto. Textos de Armando Freitas Filho, Sergio Santeiro e Frederico Morais. Rio de Janeiro, Funarte, 1978.

MORAIS, Frederico (org.). Opinião 65: 20 Anos Depois. Rio de Janeiro, Galeria de Arte Banerj, agosto de 1985.

RUBENS GERCHMAN: caixa de fumaça. Rio de Janeiro, Centro Cultural Banco do Brasil, 4/dez./2001 a 3/fev./2002.

\section{Filme}

FONTOURA, Antonio Carlos da. Ver Ouvir. Brasil, 1966. 